\title{
Ars scientia mores: science comes to English dentistry in the seventeenth century. 1. Medical publications and the Royal Society
}

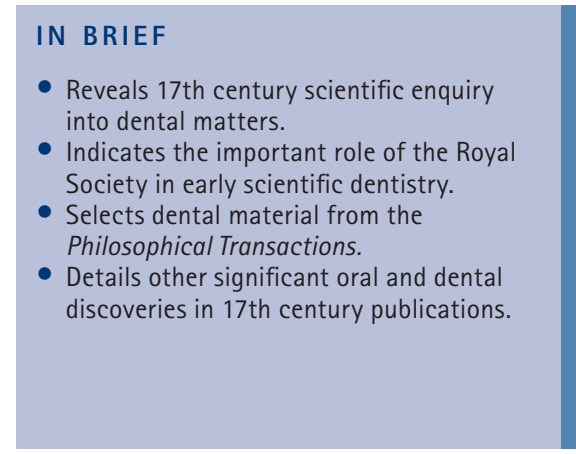

\section{Bishop ${ }^{1}$}

During the late seventeenth century scientific knowledge came dentistry, much of it through the activity of the new Royal Society, which was initiated by gatherings in London and Oxford from 1645 and formally established in 1660 after the restoration of the monarchy. The Society received its first charter from Charles II in 1662 and from 1665 onwards published its Philosophical Transactions. This paper outlines items published in that journal, and other relevant scientific publications of the century, applicable to dentistry. A companion paper employs Allen's dental treatise, The operator for the teeth, first published in York in 1685 to provide the evidence that he was aware of several of these scientific findings of his day.

\section{INTRODUCTION}

By 1700 , some dozen reports in the Philosophical Transactions of the Royal Society had dealt with subjects relating to the mouth and teeth. Not a high number until it is remembered that in these early years there was no targeted enquiry into dental matters - these were all incidental. Moreover, several were of exceptional importance to the understanding of the mouth.

As stated on the title page of the Philosophical Transactions, (Fig. 1) the Society took note of scientific advances not just in England, but 'in many considerable parts of the world', recording, among others, original investigations carried out in the Netherlands, Italy, and Denmark, as well as British case reports. This is how the discoveries on oral organisms and oral tissues made by Anthoni (or Anthony) van Leeuwenhoek (1632-1723, elected Fellow of Royal Society [FRS] 1680) of Delft were made known in Britain.

Other contributions relevant to the mouth and dental matters were received from Bellini (of Pisa), Malpighi (Messina and Bologna) and Bartholin (of Copenhagen).

${ }^{1}$ Honorary Research Fellow, History of Dentistry, King's College London Dental Institute

Correspondence to: Malcolm Bishop

Email:malcolmbishop57@btinternet.com

\section{Refereed Paper}

Accepted 10 October 2012

DOI: 10.1038/sj.bdj.2013.156

${ }^{\circledR}$ British Dental Journal 2013; 214: 181-184
To the 17th century's material made available through the Philosophical Transactions should be added William Harvey's (1578-1657) work on the circulation of the blood, ${ }^{1}$ published in 1628 and completed by Malpighi's (1628?-1694, elected FRS 1669) description of the capillary vessels, ${ }^{2}$ Thomas Wharton's (1614-1673, not a Fellow of the Society) work on the salivary glands of $1656,{ }^{3}$ Richard Lower (1631-1691, elected FRS 1667, ejected 1775) and Thomas Willis's (1621-1675, elected FRS 1661/3) dissections of the nerves, head and brain of $1664,{ }^{4}$ illustrated by Christopher Wren (1632-1723, elected FRS 1660).

\section{THE PHILOSOPHICAL TRANSACTIONS}

The original entries in the Philosophical Transactions are now made generously available to all by the Royal Society online ${ }^{5}$ and the extracts given below should serve to show just how much was being made clear, and above all shared, through scientific enquiry, publication and debate.

The earliest account of relevance to the mouth, with a passing reference to the importance of teeth and to comparative dental anatomy, appears in 1665 in a book review. ${ }^{6}$ The main subject is the tongue and the mechanism of taste, with particular reference to the function of the papillae and the nerve supply to them. Laurence Bellini (1643-1703, not a Fellow) of Pisa gives

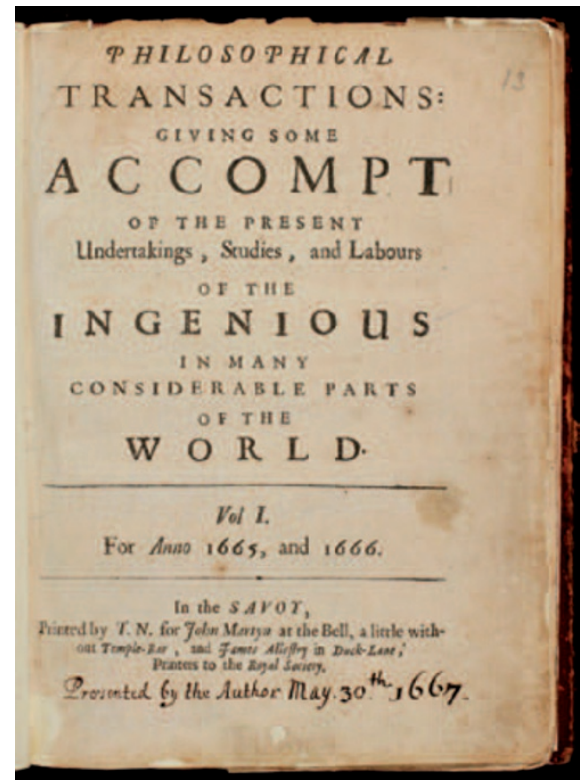

Fig. 1 Title page of the first volume of Philosophical Transactions. By kind permission of the Royal Society

credit to the prior discoveries of Malpighi.

He notices that it is the papillae on the tongue surface that are the organs of taste and that salts are the main sense of the tongue, adding that; "The Teeth in grinding the Food, serve much to extract this salt: And he notes by the by, that the Teeth are so necessary for preparing the aliment, that certain Animals which seem to have none, have them in their stomach; and that nature has put at the entry of the palat [sic] of those that are altogether destitute of them, certain movable inequalities, which are to them instead of Teeth. ${ }^{6}$ 
In 1666 an anonymous review of Malpighi's own work on the structure and function of the tongue appeared. ${ }^{7}$ In addition to the findings about the structure of the tongue repeated by Bellini, the reviewer noted Malphighi's observation that the active part of wine could be absorbed directly through the mouth without being swallowed. Malphighi's de Pulmonibus describing the capillaries in the lungs of frogs and completing Harvey's circulation, had been published in 1661 and it is notable that Allen writing 25 years later mentions 'capillary arteries', and 'capillary veins' in the internal circulation of the teeth. ${ }^{8}$ Malpighi's relationship with the Royal Society was so strong that as well as being a Fellow, it was to them that he entrusted his experimental record, published by the RS in $1696 .{ }^{9}$

\section{SALIVARY CALCULI}

Two related entries of considerable clinical interest are found in the accounts, one given in 1672 by Martin Lister (1639-1712, elected FRS 1671), the other in 1698 by a Mr Bonavert (dates unknown, not a Fellow) of an incidence of a severe infection interpretable as a Ludwig's Angina (Bonavert describes it as a Quinsie, Lister as a Distemper) each resulting from a large submandibular calculus. ${ }^{10,11}$

Lister's account is graphic; 'the place where it was lodged suddainly swelled, and ran purulent matter at the aperture of the ductus Whartonianus: that it suddenly stopped of its runing. and swelled with a great inflammation, and very great danger of choaking; it being scarce credible, what pain the party suffered in endeavouring to swallow even beer, or any liquid thing.'

Thomas Wharton published his Adenographia; sive glandularum totius corporis descriptio ${ }^{3}$ in 1656, 16 years before this description. That Lister, whose main interest outside medicine lay in spiders and snails, should have known of Wharton's anatomical discoveries demonstrates his attention to important contemporary developments in his profession as a physician. Reading Latin was of course a given for a medical man.

'Upon the incision, which proved not wide enough, the membrane of baggs, wherein the Stone lay, came away first. As to the Stone it self, it was so hard as to endure the forcipes in drawing it forth: it was covered over with grass green matter, which soon dryed, and left the stone of a whitish colour, as it is to be seen. It is but light in proportion to its bulk, weighing about seven grains [c. $4.5 \mathrm{mg}$ ]; and 'tis much of the shape of our ordinary horsebeans [or broad bean]. There are visible impressions upon it of some Capillary and small vessels, it was bred among. Lastly it is scabrous or rough, sand-like, although the substance is Tophaceous.' [The result of accretions (as, for example, gouty tophi). The word has also been used to describe calculus on the teeth].

Bonavert's stone, similar in size and appearance to Lister's, is illustrated in the transactions with a medallion for size comparison and his case resolved in the end by the patient being delivered of "near the Quantity of a quarter of a Pint of Matter, and with it at last the Stone'.

Lister's account takes on new importance when, as identified by Anna Marie Roos in her biography of Lister, ${ }^{12}$ it is realised that the patient had been Lister himself and that he had in his own words "been very dangerously ill' ${ }^{13}$ in the September of 1671. He had permitted the account to be published as long as he was not identified.

In 1684 the Danish anatomist Caspar Bartholin the younger (1655-1738, not a Fellow) contributed an extensive piece on the anatomy of the salivary glands, including his description of the eponymous Bartholin's duct of the sublingual gland. As with quite a few entries at the time, Bartholin's was in Latin, De ductu salivali hactenus non descripto, observatio anatomica. (Anatomical observation on previously undescribed salivary ducts). ${ }^{14}$

\section{ANTHONI VAN LEEUWENHOEK}

Van Leeuwenhoek is the most significant of the contributors. He considered the mechanism of taste in $1675,{ }^{15}$ comparing salt, sugar and manna, (probably honeydew) and although he does not mention Lucretius ${ }^{16}$ (Titus Lucretius Carus c. 99BCc. 55BC) attributes their differences to their physical structure (their 'figure') and different solubility. He returned to the subject of the microscopic structure of the papillae of the tongue in animals in 1707, of interest for two reasons: the use of the word thrush to describe the white matter on the tongue's surface, which he says he has investigated, and his first impression that taste did not come from the tongue alone. ${ }^{17}$

Leewenhoek wrote to the Transactions on the structure of teeth and bones in $1677,{ }^{18}$ on animals in the scurf of the teeth $1683,{ }^{19}$ on the cells of the oral mucosa in $1683^{20}$ and again (in passing) in $1693 .{ }^{21}$ The engravings that illustrate his letters are important historical records, but his talent for written description brings his findings to life. For example in $1693^{22}$ when describing animalcules in calculus, the 'gritty matter from between my Teeth', some of them moving 'with a very strong and swift motion like Eeles', others 'turned themselves round like a Top', and the smallest moved 'swiftly by each other like Gnats playing in the Air'. Most of the matter was inanimate, although structured; 'long slender parts all of a thickness'.

These contributions are rightly famous for their microscopic discoveries of the structure of the mouth and teeth and for what we now know to be bacteria and other organisms associated with the teeth and the inorganic component of calculus. Allen repeats the information concerning the internal structure of teeth, but regarded calculus as a mechanical destroyer of the gingivae and supporting bone, the link between bacteria and infection not being established until Robert Koch in $1876 .^{23}$

These extracts from Leeuwenhoek's description of the oral mucosa show how his work was presented in the Transactions; 'In my Letter of the 17th September 1683 [he is writing on 28 December 1683] I said that the skin is covered with Scales. I have since that time examined the Cuticula of the inside of the Mouth, and chiefly that of the under Lip; which I find to be covered with scales, greater and broader than those upon the Body; but they are withal thinner... as the Scales of our body, lying over one another so as to be three deep, are the cause of the skins appearing white so the scales of our Mouth, (for as much as I can yet find) lying but a little over the sides of one another, suffer the redness of the flesh and blood to appear through them; and for this cause the Lips and Mouth are red. ${ }^{20}$

In 1695 Leeuwenhoek recounted pulling out one of his own teeth. 'I cannot forbear telling you that I had again a Tooth in my Mouth, which being moveable, did hinder me very much in eating, I did deign to press hard against it with my Thum, in mind to pull the Roots of the 
Tooth out of the Flesh, and thus to get rid of the tooth, likewise it did succeed. The Top of the Tooth was almost gone, and its Root did consist of Two Branches, which was likewise extraordinarily whole, and filled up with a soft stuff. I took out this Stuff of the Roots, and mixt it with fair rain Water, [previous experimentation by him had established that rain-water and saliva were sterile] and put it thus before the Microscope, to see if there were living Animals in it and I must confess that the whole Stuff seemed to be alive, and the Number of these Animals was very great, and besides this, so little, that some of them, with a Thousand Million of others, would not make up a great Sand Corn and the number seemed bigger than it was really, because the Animals swimming so quick in the Water, did move a great many particles without Life, in a manner, that many would have taken these Particles to be living Creatures. ${ }^{24}$

Leewenhoek's final contribution of the century (though not his final contribution to the Society) in 1700 is particularly important for its importance to dentistry. As mentioned very briefly in a previous paper in the $B D J^{25}$ he had identified some ostensible tooth-worms, which had been sent to him, having been said to be smoked out of decayed teeth as cheese mites. ${ }^{26}$ The Royal Society Motto is nulla in verbis, which has loosely been translated as 'take no-one's word for it' and this is a good example of science putting folklore, and the potential for notorious scams with smoking and henbane, to flight.

\section{PROVINCIAL DISCUSSION GROUPS}

In the context of Charles Allen's scientific sources Lister was practising in York from 1670 and the stone from his case after excision (if the published account can be believed) was presented to the Archbishop of York and subsequently to the Repository of the Royal Society. ${ }^{11}$ The Archbishop at the time of the operation, Richard Sterne, (1595/6-1683, Archbishop of York, 1664-1683), was not a Fellow of the Royal Society, but his successor John Dolben (1625-1686 elected FRS 1665; Archbishop of York 1683-1686) was, and it is possible that Dolben rather than Lister presented the stone to the Society. Allen's treatise carries Dolben's imprimatur, permission to publish.
Between them Lister and the Archbishop represented a presence of the Royal Society in the city that made access to the latest science of the day a possibility for someone in Allen's position. Lister moved to London in 1683, but it is probable that Allen would have known of him in York (population c. 12,000) even if they were not personal acquaintances.

The existence of some form of discussion group or meeting outside London and the universities (particularly 0xford) between physicians, the Church and lesser practitioners is of considerable interest. Horace Walpole, writing a century later from the MSS of George Vertue says; "there was then at York a club of Virtuosi, composed of Dr. Martin Lister, John Lambert esq.' and others named. ${ }^{27}$ Anna Marie Roos furthermore records that the seven physicians (Lister among them) and the apothecaries of York (Allen's rooms were with the apothecary Walter Galloway) met monthly. ${ }^{12}$ The activities of the virtuosi extended to practical subjects, and it is perhaps significant that Allen's writings contain material suggesting personal experimentation and microscope work.

It is certain that Allen was familiar with the work of Nehemiah Grew FRS (1641-1712, elected 1671), whom he quotes in his treatise. Grew was a Fellow of the College of Physicians, as well as being a Fellow of the Royal Society and from 1678-1679 was editor of Philosophical Transactions. Allen cites him, and his work on plant anatomy and physiology, ${ }^{28}$ as his authority when expounding his own theories of tooth eruption. ${ }^{29}$ This section of Allen's work does not appear until the Dublin edition, but since that appeared only a year after the York edition Allen could have come across it in either city.

Also bound into the Dublin edition/ London issue with continuous pagination after the treatise was a discourse on the beating of the pulse. By an unknown author its cited sources included Willis and his Oxford experimental collaborator Lower. For the Dublin and London reader this brought Allen's name into association with these two.

\section{SUMMARY}

Between them, Allen's treatise, the books mentioned, and the Royal Society publications mark a momentous change in dental matters. For the first time they were being treated as science-based subjects, therefore fit for enquiry by the best minds. In particular the microscope work of van Leewenhoek was seminal, and when Sir John Tomes FRS (1815-1895, elected 1850) and his son Sir Charles Sissmore Tomes, also FRS (1846-1928, elected 1878) became engrossed in the microscopic investigation of teeth, ${ }^{30,31}$ they were continuing in van Leeuwenhoek's path.

Those interested may take advantage of the generosity of the Royal Society in making the material of the Philosophical Transactions freely available and the study of these original sources is much to be recommended.

The kind assistance of the Library of the Royal Society and the librarians and curators of the British Dental Association is gratefully acknowledged.

1. Harvey W. Exercitatio anatomica de motu cordis et sanguinis in animalibus. Frankfurt: Guilielmi Fitzeri, 1628.

2. Malpighi M. De pulmonibus observationes anatomicae. Bologna, 1661

3. Wharton T. Adenographia; sive glandularum totius corporis descriptio. London: Amstelaedami, 1659.

4. Willis T. Cerebri anatome. London: James Flesher for John Martyn and James Allestry, 1664.

5. Philosophical Transactions. Online articles available at http://rstl.royalsocietypublishing.org/ (accessed January 2013).

6. Bellini L. Gustus organum in; an account of some books lately published. Phil Trans 1665-1666; 1: 366-367.

7. Anon. An account of some discoveries concerning the brain, and the tongue, made by Signior Malpighi, Professor of Physick in Sicily. Phil Trans 1666; 2: 23-32, 491-492.

8. Allen C. The operator for the teeth. York: John White, $1685 \mathrm{p} 4$.

9. NNDB. Marcello Malpighi. Online profile available at http://www.nndb.com/people/033/000095745/ (accessed January 2013).

10. Bonavert. An Account of a stone bred at the root of the tongue, and causing a Quinsie. Communicated by Mr. Bonavert. Phil Trans 1698; 20: 440.

11. Lister M. An account of a stone cut out from under the tongue of a man; lately sent in a letter of Mr.Listers to His Grace the Lord Arch-Bishop of York. Phil Trans 1672: 7: 4062-4064.

12. Roos A M. Web of nature: Martin Lister (1639-1712), the first arachnologist. Leiden: Brill, 2011.

13. Hall A R, Hall M B (eds). The correspondence of Henry Oldenburg. Vol. VIII 1671-1672. Madison: University of Wisconsin Press, 1965-1986.

14. Bartholini C. Thom. F. De ductu salivali hactenus non descripto, observatio anatomica. Phil Trans 1684; 14: 155-166, 749-756.

15. van Leeuwenhoek $A$. Other microscopical observations, made by the same, about the texture of the blood, the sap of some plants, the figure of sugar and salt, and the probably cause of the difference of their tasts [sic]. Phil Trans 1675; 10: 380-385.

16. Melville $R$ (trans). Lucretius on the nature of the universe. Oxford: Oxford University Press, 1997. Book IV. Lines 615-672.

17. van Leeuwenhoek A. Microscopical observations upon the tongue; in a letter to the Royal Society from Mr. Anthony Van Leeuwenhoek F.R.S. Phil Trans 1683-1775: 26: 111-123.

18. van Leeuwenhoek A. Microscopical observations of the structure of teeth and other bones: made and communicated, in a letter by Mr. Anthony Leeuwenhoeck Phil Trans 1677: 12: 1002-1003. 
19. van Leeuwenhoek A. An abstract of a letter from Mr. Anthony Leewenhoeck at Delft, dated Sep. 17. 1683. Containing some microscopical observations, about animals in the scurf of the teeth, the substance call'd worms in the nose, the cuticula consisting of scales Phil Trans 1684; 14: $568-574$.

20. van Leeuwenhoek $A$. An abstract of a letter from Mr. A. Leevvenhoeck of Delft, dated Decemb. 28th, 1683. concerning scales within the mouth, etc. Phil Trans 1684; 14: 586-592.

21. van Leeuwenhoek $A$. An extract of a letter from Mr. Anth. Van. Leeuwenhoek, containing severa observations on the texture of the bones of animals compared with that of wood: On the bark of trees: On the little scales found on the cuticula, etc. Phil Trans 1693; 17: 838-843.

22. van Leeuwenhoek $A$. An extract of a letter from Mr. Anth. Van Leuwenhoek, concerning animalcules found on the teeth; of the scaleyness of the skin Phil Trans 1693; 17: 646-649.

23. NNDB. Robert Koch. Online profile available at http://www.nndb.com/people/618/000091345/ (accessed January 2013).

24. van Leeuwenhoeck $\mathrm{A}$. Part of a letter of Mr. Anthony van Leeuwenhoeck, dated delst, Sept. 10. 1697. concerning the eggs of snails, roots of vegetables, teeth, and young oysters. Phil Trans 1695; 19: $215-235,790-799$.

25. Bishop M. The ethics of dental practice in London in the sixteenth century. 1. Henry Chettle's Kind-Harts Dreame of 1592. An important lay view. Br Dent J 2012: 213: 27-30.

26. van Leeuwenhoek $A$. Part of two letters from $\mathrm{Mr}$ Anthony Van Leeuwenhoek F.R. S. concerning worms pretended to be taken from the teeth. Phil Trans 1700; 22: 635-642.

27. Walpole H. A catalogue of engravers: who have been born or resided in England; from the MSS of Mr. George Vertue. London: J. Dodsley, 1786

28. Grew N. The anatomy of plants [comprising the anatomy of vegetables begun, the anatomy of roots, the anatomy of trunks, the anatomy of leaves, the anatomy of flowers, the aatomy of fruits, etc] with an idea of a philosophical history of plants; and several other lectures, read before the Royal Society. 2nd ed. London, 1682.

29. Allen C. Curious observations in that difficult part of chirurgery relating to the teeth.to which is added, a physical discourse wherein the reasons of the beating of the pulse et.are explained. VII. The acceleration of teeth. Dublin: William Whitwood, 1687.

30. Cope Sir Z. Sir John Tomes, a pioneer of British dentistry. London: Dawsons of Pall Mall, 1961.

31. Tomes J. On the presence of fibrils of soft tissue in the dentinal tubes. Phil Trans 1856; 146: 515-522. 